\title{
Changes in foot posture and function following total knee replacement surgery
}

\author{
Pazit Levinger ${ }^{1 *}$, Hylton B Menz ${ }^{1}$, Adam D Morrow ${ }^{1}$, Julian A Feller ${ }^{1}$, John R Bartlett ${ }^{2}$, Mohammad R Fotoohabadi ${ }^{1}$, \\ Neil Bergman ${ }^{2}$
}

From 3rd Congress of the International Foot and Ankle Biomechanics Community

Sydney, Australia. 11-13 April 2012

\section{Background}

Knee malalignment and variations in foot posture and function affect the forces transmitted through the knee joint and are associated with knee pain and medial tibiofemoral cartilage damage [1]. However, it is unclear whether altered foot posture and function are a compensatory mechanism to accommodate knee malalignment. Therefore, this study investigated changes in foot posture and function after realignment of the knee following total knee replacement (TKR) in people with medial compartment knee OA.

\section{Materials and methods}

Nineteen patients ( 6 females and 13 males; mean age $67.5 \pm 5.9$ years, height $169.1 \pm 9.9 \mathrm{~cm}$, mass $87.9 \pm$ $11.8 \mathrm{~kg}$ and BMI $31.0 \pm 5.7 \mathrm{~kg} / \mathrm{m} 2$ ) diagnosed with predominantly medial compartment knee OA who were scheduled for TKR surgery participated in the study, and were tested prior to and 12 months after TKR. Foot Posture Index (FPI) and arch index were measured as well as motion of the tibia, rearfoot and forefoot using a 3D motion analysis system incorporating a multisegment foot model (Oxford Foot Model).

\section{Results}

Significant increases in tibial external rotation $(-18.7 \pm$ $7.0^{\circ}$ vs $\left.-22.5 \pm 8.7^{\circ}, \mathrm{p}=0.002\right)$ and tibial transverse plane range of motion (ROM) $\left(-9.1 \pm 4.6^{\circ}\right.$ vs $-11.4 \pm$ $\left.6.1^{\circ}, \mathrm{p}=0.0028\right)$ were observed following the surgery. An increase in rearfoot ROM in the frontal plane $(8.6 \pm$ $2.6^{\circ}$ vs $10.4 \pm 2.7^{\circ}, \mathrm{p}=0.002$ ) and a decrease in rearfoot transverse plane $\mathrm{ROM}\left(8.7 \pm 5.3^{\circ}\right.$ vs $5.9 \pm 4.1^{\circ}$,

\footnotetext{
* Correspondence: p.levinger@latrobe.edu.au

${ }^{1}$ Musculoskeletal Research Centre, La Trobe University, Melbourne, VIC, 3086 Australia

Full list of author information is available at the end of the article
}

$\mathrm{p}=0.038)$ were observed. No significant differences were found between pre and post-surgery in the FPI and or the arch index.

\section{Conclusions}

Following TKR, there is an increase in the ROM of the rearfoot in the frontal plane, but no change in static foot posture suggesting that rearfoot motion compensates for changes in the alignment of the knee.

\section{Author details}

'Musculoskeletal Research Centre, La Trobe University, Melbourne, VIC, 3086 Australia. ${ }^{2}$ Warringal Medical Centre, Melbourne, Vic, 3084, Australia.

Published: 10 April 2012

\section{Reference}

1. Wada M, Maezawa Y, Baba H, Shimada S, Sasaki S, Nose Y: Relationships among bone mineral densities, static alignment and dynamic load in patients with medial compartment knee osteoarthritis. Rheumatology 2001, 40:499-505.

\section{doi:10.1186/1757-1146-5-S1-P17}

Cite this article as: Levinger et al:: Changes in foot posture and function following total knee replacement surgery. Journal of Foot and Ankle Research 2012 5(Suppl 1):P17.

Submit your next manuscript to BioMed Central and take full advantage of:

- Convenient online submission

- Thorough peer review

- No space constraints or color figure charges

- Immediate publication on acceptance

- Inclusion in PubMed, CAS, Scopus and Google Scholar

- Research which is freely available for redistribution

\section{Ciomed Central}

